\title{
CONCEPTUAL BASES OF INVESTMENT SUPPORT OF ORGANIC PRODUCTION DEVELOPMENT IN AGRICULTURAL ENTERPRISES
}

H. A. KHARCHENKO, PhD in Economics, Associate Professor of the Department of Management named after Professor J. S. Zavadskyi National University of Life and Environmental Sciences of Ukraine ORCID 0000-0002-0705-447X E-mail: kharchenko.a.a@ nubip.edu.ua

\author{
O. A. MAZUR, the Master of Management \\ National University of Life and Environmental Sciences of Ukraine \\ ORCID 0000-0002-24270473 \\ E-mail: sannymagro@gmail.com
}

\begin{abstract}
The article substantiates and analyzes the main approaches to the interpretation of economic categories "investment support" and "investment support for development". Peculiarities of investment support for domestic enterprises engaged in the production of organic products are analyzed in the article. The necessity and prospects for the development of organic production of agri-food products as an innovative direction of agrarian business are substantiated. It has been proven that the investment support of organic agricultural enterprises involves systematic management and includes several interrelated components. The expediency of determining the sources and volumes of investment resources that can be attracted by the enterprise for the production of organic products is substantiated; priority areas for the development of effective methods of using investment resources have been identified. The main types of investments aimed at the production of organic products are identified. Theoretical and practical aspects of organic production in Ukraine are considered. The main indicators of organic production by domestic producers are analyzed. The main types of organic products in Ukraine, the total number of certified enterprises, and the area involved in the production of organic products are identified. The main ecological, economic, and social advantages of organic production are described. The main factors hindering the attraction of investments in the development of organic production are investigated. The system of financial, economic, organizational, social, and legal measures that will ensure the formation of a system of investment support for the development of agricultural enterprises engaged in the production of organic products were offered.

Keywords: investments, investment support, investment development, agricultural enterprises, organic products, sustainable development.
\end{abstract}

Introduction. The current stage of the development of agricultural enterprises is characterized by a steady trend to increase production capacity, search for 
innovative forms and methods of management and production alternatives, diversification of agricultural production. It should be noted that today organic production is one of the most promising alternative ways of doing business, aimed at economic, environmental, and social growth. Besides, organic production is a sustainable model of the agricultural sector [3]. The products of companies that produce organic products have the potential to meet the growing demand for environmentally friendly products. At the same time, the demand for organic products in many countries of the world significantly exceeds the supply, which is promising for agricultural enterprises in Ukraine. That is why, in order to study the prospects for the development of the organic market, the study of investment support for the production of organic products in Ukraine and the world is quite relevant and timely.

Analysis of recent researches and publications. The works of such domestic scientists as $\mathrm{N} .{ }^{\circ} \mathrm{M} .{ }^{\circ}$ Andreeva, $\quad \mathrm{V} .{ }^{\circ}{ }^{\circ} .{ }^{\circ}$ Artysha, $\mathrm{O} .{ }^{\circ} \mathrm{B} .{ }^{\circ}$ Vinyukova, $\mathrm{O} .{ }^{\circ} \mathrm{M} .{ }^{\circ}$ Dovgan, L. ${ }^{\circ} \mathrm{Y}^{\circ}$ Kucher, I. ${ }^{\circ} \mathrm{O} .{ }^{\circ}$ Melnyk, O. ${ }^{\circ}$ B. ${ }^{\circ}$ Nazarkevich, S. ${ }^{\circ} \mathrm{P} .{ }^{\circ}$ Tkachuk, G. ${ }^{\circ} \mathrm{A} .{ }^{\circ}$ Chugriy, and others are devoted to the issue of investment support for organic production of agricultural products. At the same time, the issues of measures aimed at improving the investment support of organic production in domestic enterprises need further research.

Purpose. The purpose of the article is to determine the conditions for the development of organic agricultural production, development and justification of ways to increase the efficiency of investment support for organic production, which will contribute to the greening of agricultural production, and improve the quality of agricultural products.

Materials and methods of research. The following main research methods were used in the research process: monographic, comparison, methods of analysis and synthesis, abstract logical, economic statistical.

Results of the research and their discussion. It is well known that the domestic agricultural sector of the economy significantly influences the formation of gross domestic product, ensuring food security of the country and its food 
independence. At the same time, one of the important strategic tasks for Ukraine during the food security formation is the greening of agricultural production, where an important place belongs to increasing the production of organic products.

It should be noted that the provision of various types of resources of organic agriculture and its effective innovative development in modern conditions directly depends on the volume and structure of the investment. Investments in agriculture, which are aimed at meeting the food needs of the domestic population by improving the land as a natural resource, creating new varieties of plants and breeds of animals, etc., will have an economic effect, in turn, associated with the goals of the organic development of agricultural production, as well as improving the efficiency of its operation $[1 ; 12]$.

Exploring the concept of investment support, economists characterize it from different positions. Approaches to determining the essence of investment support are systematized in Table 1 .

\section{Systematization of approaches to the interpretation of economic}

\section{categories "investment support" and "investment development support"}

\begin{tabular}{|l|l|}
\hline \multicolumn{1}{|c|}{ Author, source } & \multicolumn{1}{|c|}{ Interpretation of economic category } \\
\hline Parakonny S. V. & $\begin{array}{l}\text { Investment support is all types of property and intellectual values that are } \\
\text { invested in entrepreneurial and other activities, as a result of which income is } \\
\text { generated or a social effect is achieved }\end{array}$ \\
\hline Kapitanec Yu. O. & $\begin{array}{l}\text { Investment support is a set of conditions, resources, and measures necessary } \\
\text { for the implementation of the investment process }\end{array}$ \\
\hline Kisil M. I. & $\begin{array}{l}\text { Investment support is not only the formation of sources of investment } \\
\text { financing but a set of various conditions, resources, economic mechanisms, } \\
\text { levers, and measures necessary to ensure the normal (set) flow of investment } \\
\text { processes }\end{array}$ \\
\hline Shevtsova Ya. A. & $\begin{array}{l}\text { Investment support - a system of measures for concentration and } \\
\text { implementation of investments and the choice of rational management } \\
\text { methods in the field of investment }\end{array}$ \\
\hline Shilova O. Yu. & $\begin{array}{l}\text { Investment support for enterprise development - a subsystem of } \\
\text { organizational and economic support, designed to cover production costs and } \\
\text { accumulation in order to increase production and sales, whose resources are } \\
\text { formed in compliance with the principles of long-term, optimality, } \\
\text { alternative }\end{array}$ \\
\hline Kodenska M. Yu. & $\begin{array}{l}\text { Investment support - organizational and economic conditions, means, } \\
\text { measures, and economic relations that are manifested in the movement of } \\
\text { value advanced to capital in order to form, accumulate and use investment } \\
\text { resources for the development of agro-industrial production and human - the } \\
\text { main productive force of society }\end{array}$ \\
\hline
\end{tabular}

Source: formed on the basis $[2 ; 4-7 ; 9 ; 10]$. 
Note that the investment support for the development of agricultural enterprises involves multifaceted management and includes several interrelated components (Fig. 1).

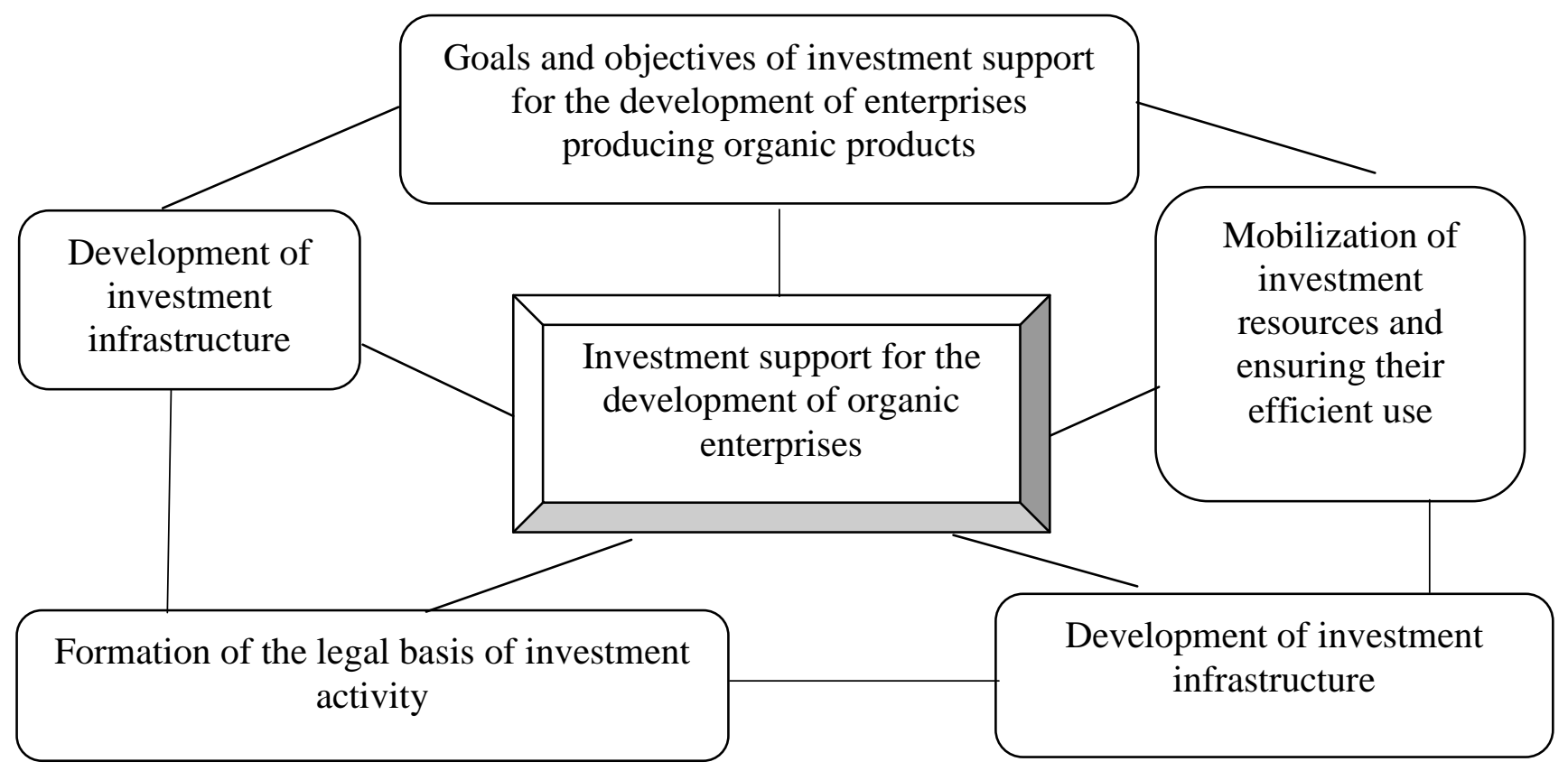

Fig. 1. Investment support for the development of the agricultural enterprises engaged in the production of organic products

Source: formed on the basis $[1 ; 6 ; 12]$.

Note that the development of agriculture requires large-scale and effective investment. For a successful and effective forming of investment support in organic agricultural enterprises it is necessary to determine the sources and amounts of investment resources that can be attracted by the enterprise; identify the main, priority areas, and develop effective methods for using investment resources. The sources of investment resources of agricultural enterprises engaged in the production of organic products are own, borrowed, and borrowed funds (Table 2).

We will note that one of the most important sources of investment support for enterprises' development is their means, namely undivided profit and depreciation deductions. Among the sources of investment support for agricultural enterprises, the main and dominant importance should be their own sources, the main of which is profit. 


\section{Sources of investment support for the development of organic}

agricultural enterprises

\begin{tabular}{|l|l|l|}
\hline \multicolumn{1}{|c|}{ Own } & \multicolumn{1}{|c|}{ Involved } & \multicolumn{1}{c|}{ Borrowed } \\
\hline $\begin{array}{l}\text { Domestic } \\
\text { Foreign }\end{array}$ & Payables & \multicolumn{1}{c|}{ Loans: } \\
Funds generated in the process of activity: & & $\begin{array}{l}\text { Boans loans } \\
\text { foands: } \\
\text { and organizations institutions } \\
\text { Budget loans on a revolving } \\
\text { basis }\end{array}$ \\
$\begin{array}{l}\text { Undivided profit } \\
\text { Depreciation of fixed assets }\end{array}$ & \\
\hline \multicolumn{1}{|c|}{ Budget financing } & & \\
\hline
\end{tabular}

Source: formed on the basis $[9 ; 10]$.

We will note that the land resource potential of Ukraine has special opportunities to develop in the direction of organic production [7]. The production of organic products in Ukraine shows positive indicators. Thus, in 2019, almost 600 organic agricultural producers were operated in Ukraine. In general, Ukraine ranks twenty-fourth in the world and eleventh in Europe in the area of agricultural land under organic production (309 thousand hectares).

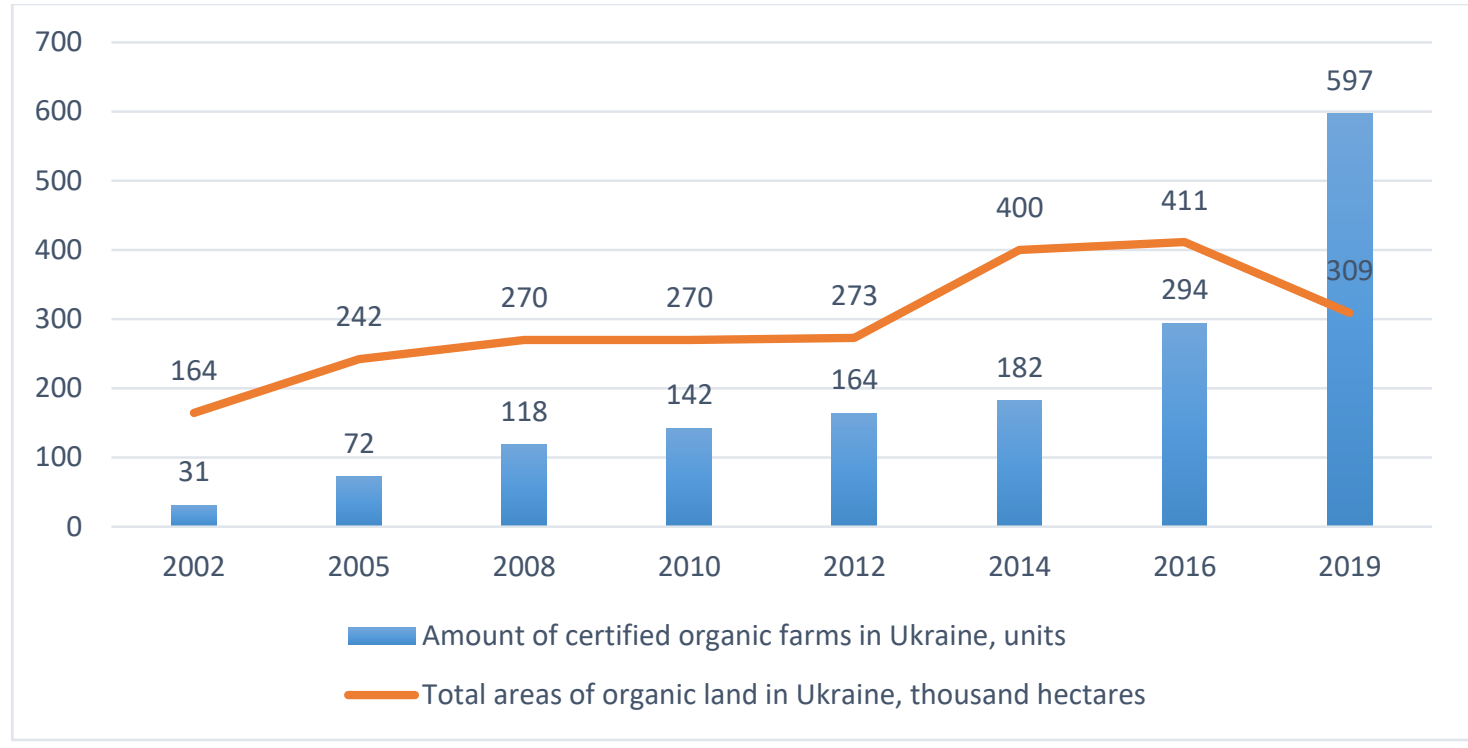

Fig. 2. Organic production in Ukraine

Source: [9].

At the same time, more than 150 domestic producers export their organic products to more than forty countries, which accounts for $90^{\circ} \%$ of the total amount of all organic products in Ukraine [9]. In the structure of sown areas in Ukraine, almost $60^{\circ} \%$ of crops are wheat, barley, sunflower, and corn. The rest of the area is occupied 
by crops such as peas, rapeseed, buckwheat, rye, soybeans, oats, sorghum, millet, sugar beets, and others. The structure of domestic organic products for export is dominated by cereals, oilseeds, and legumes, as well as berries and fruits [6;9].

Currently, the following organic products have been certified in our country: cereals, legumes, and oilseeds, essential oils, vegetables, grapes, watermelons, melons, pumpkins, fruits, berries, nuts, dairy products, eggs, mushrooms, bee products, perennial and annual herbs, medicinal plants, cattle, poultry, goats, pigs, teas, and juices. The vast majority of domestic farms engaged in the production of organic products are located in Odesa, Zhytomyr, Kyiv, Poltava, Kherson, Vinnytsia, Zakarpattia, Lviv, and Ternopil regions [9].

It should be noted that Ukrainian agricultural producers are generally interested in organic production, which is explained by its benefits related to the preservation of the environment in the production process, improving soil structure that helps to increase its fertility. At the same time, organic products contain more nutrients, minerals, and vitamins by minimizing chemicals. Also, organic production is characterized by environmental, economic, and social benefits (Fig. 3). Thus, providing the population with quality and safe organic food helps to improve the health of the population and increase the level of food security in the country. Studies show that organic products contain $63^{\circ} \%$ more potassium, $73^{\circ} \%$ more iron, $125^{\circ} \%$ more calcium, and $60^{\circ} \%$ more zinc than products made by the traditional production. At the same time, organic management methods contribute to resource conservation, reducing the energy intensity of agricultural production, thereby increasing the competitiveness of producers in foreign and domestic markets. Increasing demand for organic products allows businesses to sell their products at a premium price and increase their revenues $[7 ; 12]$.

The transition of the agricultural sector to an innovative basis depends on the volume and sources of investment support for business projects, both in terms of modernization of technical and technological base, and in terms of establishing the production of competitive food products on the world market. 


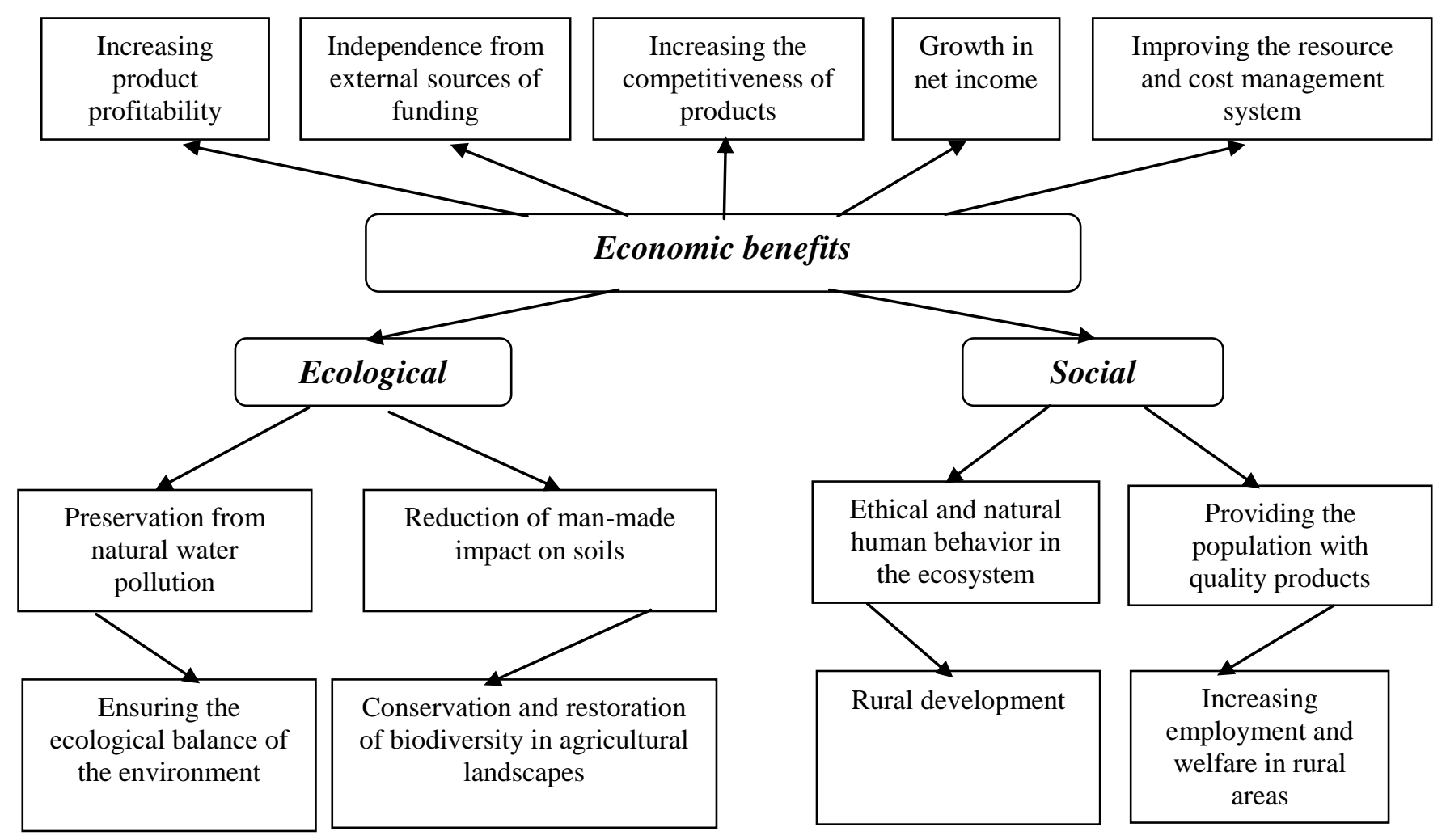

Fig. 3. Key benefits of organic production

Source: formed on the basis $[3 ; 4 ; 7 ; 12]$.

Note that the investment support for organic production is largely due to the creation of an effective mechanism for stimulating investment processes in agriculture. The current components of the system of investment attractiveness in organic agricultural production do not ensure the growth of investment activity. Studies have shown that this is due to the long period of waiting for the results of the agricultural enterprise activities, in which investments are made, and the lack of guarantees in the formation of repayment sources for investment liabilities [2;4]. Only scientifically substantiated state investment and innovation policy can promote the transition of the domestic agricultural sector to an innovative model of sustainable development of organic agricultural production. That is why the formation of an effective system of investment support for the development of agricultural enterprises engaged in the production of organic products requires the implementation of certain conceptual provisions through the implementation of a set of financial, economic, organizational, social, and legal measures. 
Conclusions and future perspectives. Organic farming is a production system that supports the health of soil, ecosystems, and populations. Such a system is based on ecological processes, biological diversity, and cycles adapted to local conditions. Organic agriculture combines tradition, innovation, and science to improve the environment, develop fair relations, and improve the quality of life of all participants.

The successful development of organic agriculture requires large-scale and effective investment. For successful and effective attraction of investment resources in agricultural enterprises it is necessary to determine their sources and volumes that can be attracted by the enterprise; identify the main, priority areas, and develop effective methods of using investment resources.

The market for organic products can attract investors due to several factors such as ever-increasing demand, high profitability, and unsaturated domestic market. Currently, this industry is more popular among domestic investors but there are all opportunities to attract foreign investors due to its active development and high level of profitability.

\section{References}

1. Blonskaya, V. I., \& Shlapak, I. Yu. (2011). Obgruntuvannia ta investytsiine zabezpechennia proektu rozvytku pidpryiemstva [Substantiation and investment support of the enterprise development project]. Scientific Bulletin of NLTU of Ukraine, 21(1), 159-165.

2. Capitanec, Yu. O. (2010). Investytsiine zabezpechennia fermerskykh hospodarstv [Investment support of farms]. Innovative economy, 5, 141-144.

3. Kadebska, E., Kharchenko, H., Kharchenko, V., Tereshchenko, S., \& Doroshenko, H. (2020). An analysis of modelling of the consumption of organic products and strategic for increasing its production in Ukraine. International Journal of Advanced Science and Technology, 29(8s), 250-257. Retrieved from http://sersc.org/journals/index.php/IJAST/article/view/10496

4. Milovanov, E., Melnyk, S., \& Demidov, O. (Eds). (2008). Dovidnyk standartiv YeS shchodo rehuliuvannia orhanichnoho vyrobnytstva ta markuvannia orhanichnykh produktiv. Knyha 1 [Handbook of EU standards for the regulation of organic production and labeling of organic products. Book 1]. Lviv: LA "Pyramida".

5. Kharchenko, V., \& Kharchenko, H. (2018). Modelling of investment support of use of resource potential of agricultural enterprises, Proceedings of the International Scientific Conference "Economic Sciences for Agribusiness and Rural Economy”. Retrieved from https://js.wne.sggw.pl/index.php/esar/article/view/921 
6. Kisil, M. I. (2009). Investment support for the development of agricultural production and rural areas. Management: Collection of scientific works, $11,225$.

7. Kodenska, M. Yu. (2013). Motivational factors of investment support for the development of agro-industrial production. Bulletin of the Academy of Labor and Social Relations of the Federation of Trade Unions of Ukraine, 2, 62-66.

8. Parakonny, S. V. (2011). Areas of investment support for the development of economic potential of the enterprise. Bulletin of the Volodymyr Dahl East Ukrainian National University: Science, 11(153(1)), 51-58.

9. Organic in Ukraine. Official site of Federation of Organic Movement of Ukraine. (2020). Retrieved from http://organic.com.ua/en/organic-in-ukraine/

10. Ruzhenkova, O. (2009). Organic farming: past, present, prospects. Agrarian business, 41, 9.

11. Vakhovich, I. M. (2011). Conceptual bases of investment support of innovative development of the region. Current economic problems, 1, 138-144.

12. Willer, H., \& Lernoud. J. (2020). The World of Organic Agriculture: Statistics and Emerging Trends 2020. Research Institute of Organic Agriculture (FiBL) and International Federation of Organic Agriculture Movements (IFOAM). Retrieved from https://www.arc2020.eu/wp-content/uploads/2020/03/organic-world2020.pdf

\section{КОНЦЕПТУАЛЬНІ ОСНОВИ ІНВЕСТИЦЙНОГО ЗАБЕЗПЕЧЕННЯ РОЗВИТКУ ОРГАНІЧНОГО ВИРОБНИЦТВА В СІЛЬСЬКОГОСПОДАРСЬКИХ ПІДПРИЕМСТВАХ Г. А. Харченко, О. А. Мазур}

Анотація. $У$ статті проаналізовано особливості інвестиційного забезпечення вітчизняних підприємств, щзо займаються виробництвом органічної продукиії. Обгрунтовано необхідність та перспективи розвитку органічного виробництва агропродовольчої продукиії як інноваційного напряму аграрного бізнесу. Доведено, щзо інвестиційне забезпечення органічних сільськогосподарських підприємств передбачає системне управління та включає в себе декілька взаємопов'язаних складових. Обгрунтовано доцільність визначення джерел та обсягів інвестииійних ресурсів, які можуть бути залучені підприємством для виробництва органічної продукції; визначено пріоритетні напрями щзодо розроблення ефективних методів використання інвестиційних ресурсів. Визначено основні види інвестицій, щзо націлені на виробництво органічної продукиії. Розглянуто теоретичні і практичні аспекти виробництвва органічної продукиії в Украӥні. Проаналізовано основні показники виробництва органічної продукції вітчизняними товаровиробниками. Охарактеризовано основні екологічні, економічні та сочіальні переваги органічного виробництва. Досліджено основні фактори, щзо заважають залученню інвестицій у розвиток органічного виробництва. Запропоновано впровадження заходів через реалізацію сукупності фінансових, економічних, організаційних, соціальних та правових заходів, щзо забезпечать формування 
системи інвестиційного забезпечення розвитку сільськогосподарських підприємств, щзо займаються виробництвом органічної продукиії.

Ключові слова: інвестиції, інвестиційне забезпечення, інвестиційний розвиток, сільськогосподарські підприємства, органічна продукиія, сталий розвиток. 